\title{
THE ANNUAL
}

OF THE

\section{BRITISH SCHOOL AT ATHENS}

No, XXI.

SESSIONS 1914-1915; 1915-1916.

PRINTED, FOR THE SUBSCRIBERS AND SOLD ON TIEIR BEHALF BY

MACMILLAN \& CO., LiMiTED

LONDON

PRICE TWEINTY-ONE SHILLINGS NET 


\section{THE ANNUAL}

OF THE

\section{BRITISH SCHOOL AT ATHENS}

No. XXI.

SESSIONS 1914-1915; 1915-1916

PRINTED FOR THE SUBSCRIBERS AND SOLD ON THEIR BEHALF BY

MACMILLAN \& CO., LIMITED

LONDON 


\title{
THE BRITISH SCHOOL AT ATHENS
}

\author{
PATRON.-HIS MAJESTY THE KING.
}

\section{MANAGING COMMITTEE.}

$1914-1915$.

LDWIN FRESHFILLD, EsQ., LL.D.

WaLter Leaf, Esq., Litt.D.

George A. Macmillan, EsQ., D.Litt., Chairman.

Trustees.

Professor Percy Gardner, Litt.D. Appointed by the University of Oxford.

Sir John Sandys, Litt.D. Appointed by the University of Cambridge.

Miss Jane E. Harrison, D.Litt., LL.D. Appointed by the Hellenic Society.

Miss C. A. Hutron, ex afficio as joint Editor of the Annual.

Professor R. C. Bosanquet, M.A.

Sir Arthur J. Evans, D. Litl., LI.D.

W. S. GEORGE, EsQ., A.R.I.B.A.

ProfESSOR ERNEST GARDNER, Litt.D.

D. G. Hogarth, Esq., M.A.

Professor J. Lynton Myres, M.A.

Sir Cecil Harcourt-Smith, LL.D.

M. N. Tov, Ese., M.A.

k. M. DaWkins, EsQ., M.A.

Sir Charles Waldstein, Litt.D.

L. Whibley, EsQ., M.A.

A. E. Zimmern, EsQ., M.A.

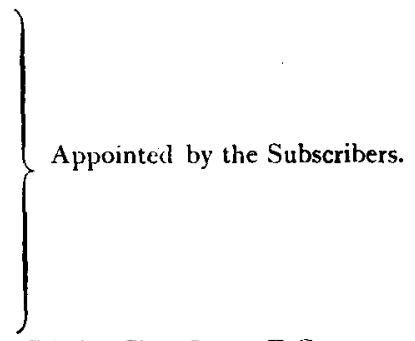

V. W. Yokke, EsQ., M.A., Hon. Treasurer, Farringdon Works, Shoe Lane, E.C. 4. John ff. B. Penoyre, Esq., M.A., Secretary, 19, Bloomsbury Square, W.C. 1.

\section{DIRECTOR, I9I4-I9I5.}

A. J. B. Wace, Esq., M.A., Fellow of Pembroke College, Cambridge.

Assistant Director and Librarian:-F. W. Hasluck, EsQ., M.A., Late Fellow of King's College, Cambridge.

$$
1915-1916 .
$$

Eowin FreshField, EsQ., LL.D.

Walter LeaF, EsQ., Litt.D.

Georgr A. Macmillan, EsQ., D. Litt., Chairman.

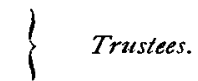

Si R John SANDys, Litt.D. Appointed by the University of Cambridge.

Miss JANe E. Harrison, D.Litt., LL.D. Appointed by the Hellenic Society.

Miss C. A. HutTon, ex officiu as joint editor of the Annual.

Professor R. C. Bosanquet, M.A.

Sir Arthur J. Eváns, D.Litt., LL.D.

H. H. Jewell, EsQ., A.R.I.B.A.

Professor Ernest Garuner, Litt.D.

D. G. Hogarth, Fsq., M.A.

Professor J. LyNtón Myres, M.A.

Sir Cecil. Harcou RT-Smith, LL.D.

M. N. TOD, EsQ., M.A.

R. M. DAwKINS, EsQ., M.A.

Sir Charles Waldstein, Litt. D.

L. Whibiey, Esq., M.A.

A. E. Zimmern, EsQ., M.A.

V. W. Yorke, EsQ., M.A., Hon. Treasurer, Farringdon Works, Shoe Lane, E.C. 4. John ff. B. l'enoyre, Esq., M.A., Secretary, I9, Bloomsbury Square, W.C. I.

DIRECTOR, I9.15-19I6.

A. J. B. WACE, Es\&., M.A., Fellow of Pembroke College, Cambridge. 


\section{TABLE OF CONTENTS:}

\section{MNHMHEXAPIN}

I. G. Dickins.

2. R. M. HEATH.

3. A. J. B. WACE.

4. W. ILAF.

5. Miss 1). Lamb.

6. F. IV. Hasidek.

$7 \quad, \quad$,

8. H. J. W. TIIT, IRI)

9. W. Leaf.

-10. Miss C. A. Hutron. 'Ihe Greek Inscriptions at Petworth House (Plate XIV.)

Two Sepulchral Inscriptions from Suvla Bay . 166

The Followers of Praxiteles (Plates I.-V.), . I

A Lament . . . . . . . . 10

The Site of Olynthus . . . . . $\quad$. 1 I

Some Problems of the Troad . . . . 16

Notes on Seljouk Buillings at Konia (Plates VI.-XI.) . . • • • • . $\quad$. $3^{\mathbf{I}}$

Stone Cults and Venerated Stones in the GraecoTurkish Area. . . . . . . . 62

Geographical Distribution of the Bektashi (Plates XII., XIII.) . $\quad . \quad \cdot \quad \cdot \quad \cdot \quad \cdot \quad 8_{4}$

Rhythm in Byzantine Music . . . . 125 The Lokrian Maidens . . . . . . 148 Some Lydian Propitiatory Inscriptions (Plate

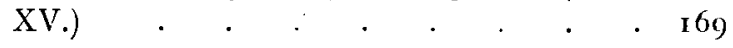


Annual Meeting of Subscribers, I914-1915 . . . . . . . . . . $\quad$ I85

Income and Expenditure, 1914-1915 . . . . . . . . . I91

Donations and Subscriptions, 1914-1915. . . . . . . . 193

Annual Meeting of Subscribers, 1915-1916 . . . . . . . . . $\quad$ 198

Income and Expenditure, r9i5-19u6 . . . . . . . . . 204

Donations and Subscriptions, I915-1916. . . . . . . . . 206

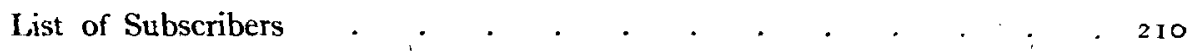

List of Directors, Honorary Students, Students and Associates . . . 215

Rules 'and Regulations of the British School at Athens . : . . 224

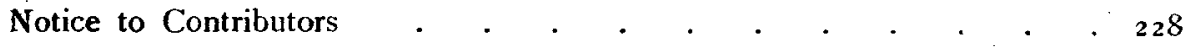

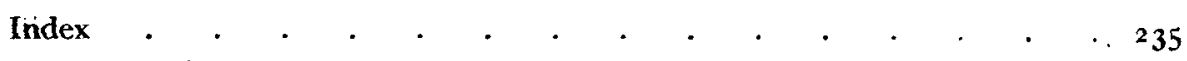




\section{LIST OF PLATES.}

I. The Followers of Praxiteles: The Drapery of the Hermes of Olympia compared with the draped Figures on the Mantinean Reliefs and the "Maiden" of Herculaneum.

II. The Followers of Praxiteles: I. Head of Hermes (Olympia). 2. Head of Aphrodite (Leconfield). 3. Head of Sarapis (Brit. Mus.). 4. Head of Eubouleus (Athens).

III. The Followers of Praxiteles: I. Head of Psyche of Capua (Naples). 2. Head of a Girl (Boston).. 3. "Sieglin" Head of Alexander.

IV. The Followers of Praxiteles: I, 3. The Capitol Venus and the Medici. Venus compared with the Cnidian Aphrodite.

V. The Followers of Praxiteles: I. Head of Niobe (Florence). 2. Head from Tegea (Athens). 3. Head of Demeter of Cnidus (Brit. Mus.). 4. Head of Bronze Statute from Anticythera (Athens).

VI. Seljouk Buildings at Konia: The Mosque of Sultan Alaeddin, I. The North Façade. 2. General View from the North.

VII. Seljouk Buildings at Konia: The Mosque of Sultan Alaeddin, r. The Great Portal. 2. Interior of the Eastern Hall.

VIII. Seljouk Buildings at Konia: The Mosyue of Sultan Alaeddin, I. Details of the Façade. 2, 3. The Turbeh and its Masjid.

IX. Seljouk Buildings at Konia: Stalactites of Corbel in the ruined Kiosk. 2, 3. The Energeh Mosque and Portal.

X. Seljouk Buildings at Konia: The Indjeh Minareli Medresseh and Portal. 3. Portal of the Kara Tai Medresseh.

XI. Seljouk Buildings at Konia: Pendentive and Dome of the Kara Tai Medresseh.

XII. Geographical Distribution of the Bektashi: I, 2. Gateway and Mosque of Tekke at Kalkandelen. 3. Christian Monastery of S. Naoum on L. Ochrida.

XIII. Geographical Distribution of the Bektashi: x. Tekke at Argyrokastro. 2. Precinct of Risk Baba, Candia.

XIV. The Greek Inscriptions at Petworth House. The Slab bearing the Ergastinai Inscription.

XV. Lydian Propitiatory Inscriptions : 1. Stele of Diokles. 2 . Stele of Apollonios. 


\section{LIST OF ILLUSTRATIONS IN THE TEXT}

The Site of Olynthus :-

PACIE

Fig. I. Sketch-Map of Chalkidiké . . . . . . . . I I

Fig. 2. Sketch-Map of the District round the Site of Olynthus . . I3

Notes on Seljouk Bulbdings at Konia :-

FIGS. I, 2. Carved Stone Slabs of Syrian Workmanship and I)esign . $3^{6}$

Fig. 3. Ground-plan of the Mosque of Alaeddin (after Sarre, Persische

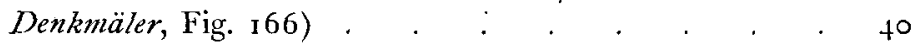

Fig. 4. Ground-plan of the Ummayad Mosque, Damascus (after Spiers, J.R.I.B.A., p. 26, Fig. 2) . . . . . . . . . . $+t^{2}$

Fig. 5. Ground-plan of the Mosque at Ayasoluk [Ephesus] (after Strzygowski, Amida, Fig. 264) . . . . . . . . 42

Fig. 6. Capital Letters from Armenian Gospels in the British Museum 53

Fig. 7. Polyhedric Pendentive of the Mosque of Alaeddin . . . $5^{6}$

Fig. 8. Pendentive of the Kara Tai Medresseh . . . . . . 58

Fig. 9. Diagram illustrating two Forms of Stalactite . . . . . 60

Geographical Distribetion of the Bektashi:-

Fig. I. Sketch-Map shewing the Distribution of the Bektashi in Asia Minor . . . . . . . to face S6

Fig. 2. Sketch-Map shewing the Distribution of the Bektashi in Europe to face roo

Fig. 3. Sketch-Map shewing the Distribution of the Bektashi in S. Albania vi

to face 114 
Rhythm in Byzantine Music:-

Fig. I. r. Kratema (two forms). 2. Diple. 3. Double Apostrophus. 4. Klasma or Tzakisma (two forms). 5. Apoderma or Apodoma (two forms). 6. Argon. 7. Gorgon. 8. Psephiston. 9. Piasma. 10. Tromikon. I I, I2. Ornamental Cadences in Round System. I3. Cadence in Cucuzelian System. 1 4. Hirmus, First Ode, from M.S. Trinity Coll. Camb., i 165 , f. 6 . . . . . . . . . . . . 128

Fig. 2. Four-fold Hallelujah from M.S. in Cambridge University Library, $A d d .293^{6}$, f. $49^{b}$ (16th-1 7 th Cent.). Mode II. (starting Note b)-Adagio . . . . . . . . . . . . $\mathrm{I}_{22}$

The Graek Inscriptions at Petworth House:-

Fig. I. Uncial Text of the Petworth Inscription published by U. Köhler (After Ath. Mitt. viii. Text-Plate to face p. 58) . . . ${ }_{15}{ }^{6}$

Fig. 2. Facsimile of Petworth Inscription as now published . . $\quad{ }_{158}$ 